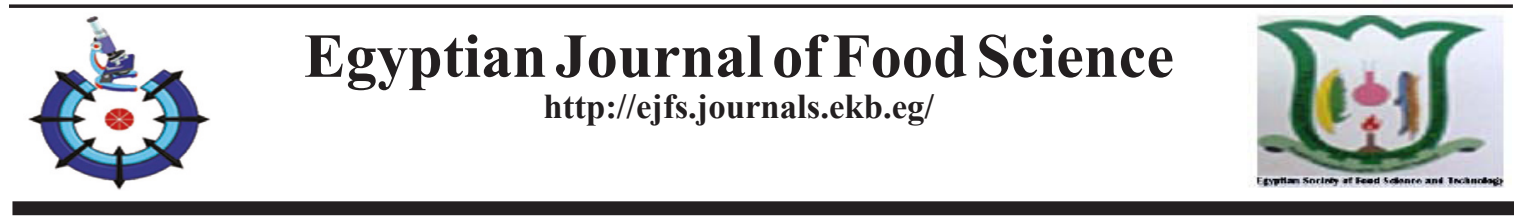

\title{
Norovirus Detection in Fresh and Vended Periwinkles (Tympanotonus fuscatus var radula) in Nigeria
}

\author{
Babalola Michael Oluyemi ${ }^{1 \#}$, Adeoyo Olusegun Richard ${ }^{2 *}$ and Odesanya Israel \\ Olamide $^{2}$ \\ ${ }^{1}$ Infectious Diseases Epidemiology, Molecular Virology, and Special Pathogens \\ Research, Department of Microbiology, Adekunle Ajasin University, P.M.B. 001, \\ Akungba-Akoko, Ondo State, Nigeria. \\ ${ }^{2}$ Department of Microbiology, Adekunle Ajasin University, P.M.B. 001, Akungba- \\ Akoko, Ondo State, Nigeria.
}

\begin{abstract}
$\mathbf{T}$ THE MAJOR enteric viral pathogens comprising the Rotavirus, Norovirus, Adenovirus and Astrovirus are commonly implicated in outbreaks of viral gastroenteritis and can be found in several fecally contaminated milieu. Consumption of oysters and other sea foods have been incriminated in food borne outbreaks of Norovirus gastroenteritis. As there are paucity of data from Nigeria, on the contraction of viral gastroenteritis via consumption of seafood, this study was aimed at detecting these viruses from commercially vended periwinkles, a popularly consumed seafood delicacy in Nigeria. Between October 2018 and March 2019 fresh periwinkle samples were collected by convenience sampling, from traders in two (2) major markets in Lagos State, Nigeria. At each market, 10 samples were collected and pooled weekly and tested for concurrent presence of four enteric viruses using Enzyme Immuno-Assay Combo kit. Results obtained were analysed using descriptive statistics and Chi square at $\alpha_{0.05}$. Out of the 48 batches analysed, only the Norovirus was found in seven (7) batches at a prevalence of $14.6 \%$ in the study area. The highest rate of detection occurred in December 2018 from Oyingbo market, while the highest monthly rate occurred in Ikotun market. No statistically significant association was found in Norovirus detection from periwinkles at the two market sites $\left(\chi^{2}=0.167, p=0.6826\right)$. Similarly, no statistically significant association in the rate of Norovirus detection and the month of sample collection $\left(\chi^{2}=8.864, p=0.115, \mathrm{df}=5\right)$. This is the first report of Noroviruses from food sources in Nigeria. The results obtained from this study indicated that periwinkles serve as reservoirs of Norovirus and can be a potential source for the outbreak of gastroenteritis and diarrhea disease in the study area.
\end{abstract}

Keywords: Periwinkles; Norovirus; Foodborne gastroenteritis.

\section{Introduction}

Some sea foods such as shellfish, periwinkles and oysters may remain contaminated by viral, bacterial and protozoa for a long period (Rivera et al., 2010). Marine gastropods such as snails, and slugs are host to a wide variety of parasites. Their prevalence and infective properties can significantly affect the population of living organisms and functioning of the ecosystem
(Coen and Bishop, 2015). Periwinkle is a common name of small snails classified within the family Littorinidae. Tympanotonus fuscatus var radula and Pachymelinia bryonensis are the two common small edible sea snails found in Nigerian brackish and fresh waters, respectively. Periwinkles are intertidal species with dark and sometimes banded shell. The rough periwinkle shell is characteristically mottled grey, white or

"Corresponding author : olusegun.adeoyo@aaua.edu.ng

\#michael.babalola@aaua.edu.ng ,

Received :20/08/2019; accepted : 17/11/2019

DOI: 10.21608/EJFS.2019.15979.1015

(C)2019 National Information and Documentation Centre (NIDOC) 
black. They could also be tapers to straight-sided or rounded cone with obtuse shape. The shell of some periwinkles may be broadly ovate, thick and sharply pointed. The shell contains six to seven whorls with some fine threads and wrinkles. The shell lacks a central depression. The white outer lip of the shell is chocolate brown chequered with brown patches (Benson, 2011).

Periwinkles are found in the zone of water close to the shore, where there is low and high tides. They may also be found in muddy environment such as estuaries of about 180 feet in depth (Benson, 2011). Periwinkles are known to harbor a wide variety of microorganisms of which viruses are included. During feeding, periwinkles use their radulae to pull algae from rocks surfaces, pick up algae from cordgrass or biofilm that covers the surface of mud in estuaries (Chang et al., 2011). Hunting for periwinkles involve handpicking from the surface of rocks or a boat. Periwinkles are sought seafood in Europe, African and Asian countries. Periwinkles have high protein content, omega-3 fatty acids and low content of fat. According to the information available in National Nutrient Database for Standard Reference, raw snails have about $80 \%$ water, $15 \%$ protein and $1.4 \%$ fat. In Nigeria, periwinkles are one of the admired food supplements in some dishes such as "Afang", "Egusi", "Ogbono", and vegetables soups (Chapman et al., 2007). Geometric mean of fecal coliform count and virus densities in seafood were found to be correlated with precipitation, agricultural wastes, fishery wastes and sewage treatment failures, which is affected by resuspension of sediment, temperature, salinity and tidal waves (Fig. 1). Studies show that the overboard disposal of sewage by oyster harvesters into oyster-bed waters was a major source of contamination to water bodies.

Norovirus is one of the enteric viruses that affect human. One can easily get infected when one feed on oysters and related seafood. Previous studies have revealed that the immunoreactivity of Norovirus was predominantly found in the lumen and tissues of digestive tract while Poliovirus was found to be active on cells of nondigestive tract tissues, as well as in labial palp and gills of oysters. The portal of entry of Noroviruses into seafood is either through contaminated seawater or improper processing handling, which may result into outbreaks of viral gastroenteritis (Ko et al., 2005; Buckwalter et al., 2012; Bosch et al., 2014; Medici et al., 2015). Outbreaks of acute viral gastroenteritis in humans associated with consumption of contaminated raw oysters occur commonly in December to March in the United States, and April to May in most parts of Europe, while this has not been determined in Africa (Wang and Deng, 2012 and Eden et al., 2014). According to Simmons et al. (2007), who reported an outbreak of norovirus infection in 2006 amongst people attending an international

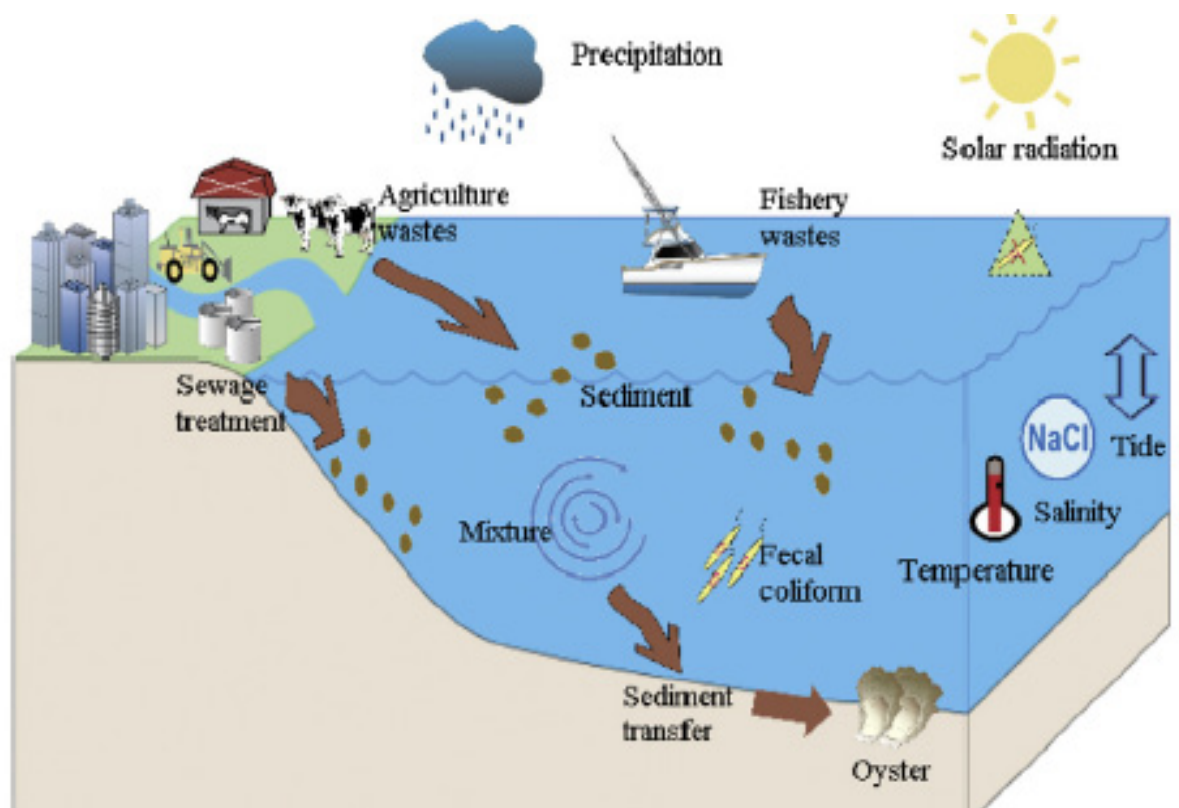

Fig. 1. Potential sources, pathways, and effects of environmental processes on oyster contamination in coastal waters (Wang et al., 2012)

Egypt. J. Food. 47, No.1 (2019) 
rugby test match at Eden Park, Auckland, New Zealand. This outbreak was strongly linked to the consumption of imported raw oysters.

The incubation period of Norovirus is relatively short between 1-2 days. It may be transmitted by infected person through fecaloral route, aerosolization and ingestion of undercooked sea foods from polluted water (Hardy, 2005 and Lee et al., 2013). Symptoms of infection norovirus infection usually last for about 24-48 hours and may include; sudden onset of diarrhoea, forceful vomiting, loose bowel motions, high body temperature and fatigue (Farthing et al., 2013). Literature searches indicated that there is paucity of information on the detection of enteric viral pathogens in oysters of Africa and potential health hazards from consumption of contaminated seafood particularly in Nigeria. In view of some reported outbreaks of gastroenteritis of unknown etiology, this research sought to detect any of the major enteric viruses associated with periwinkles.

\section{Materials and Methods}

\section{Study Area}

The study locations were Ikotun and Oyingbo markets in Lagos State, Nigeria. Lagos is the most populous state in the southwestern Nigeria with the capital in Ikeja. Lagos State is bounded on the north and east by Ogun State. In the west it shares boundaries with the Republic of Benin and its southern borders lies the Atlantic Ocean. Lagoons and creeks are $22 \%$ of its $3,577 \mathrm{~km}^{2}$. Lagos is a port which originated on islands separated by creeks, such as Lagos Island, fringing the southwest mouth of Lagos lagoon while protected from the Atlantic Ocean by barrier islands and long sand spits such as Bar Beach, which stretch up to 100 kilometres (62 miles) east and west of the mouth (Fig. 2).

\section{Specimen Collection and Preparation}

At each visit to the markets, periwinkles (Fig. 3 ) were bought and aseptically collected from 2 major markets (Oyingbo and Ikotun designated as Market A and B respectively) in Lagos state and immediately transported in cold chain to the Microbiology Laboratory of Adekunle Ajasin University Akungba Akoko where samples were immediately screened for the presence of the target viruses or stored at $-20^{\circ} \mathrm{C}$. Two batches of the samples (Market A and B) were collected per week consisting of 10 periwinkles per batch making a total of 8 batches (Market A and B) per month and 48 (Market A and B) batches over a period of 6 months. For each batch, about 10 grams of the periwinkles were dispensed into $90 \mathrm{~mL}$ of sterile phosphate buffered saline and macerated. The liquid portion was decanted aseptically, centrifuged at $3000 \mathrm{rpm}$ for $10 \mathrm{mins}$ and collected in specimen bottles. The supernatants were then labelled accordingly (Fig. 4 and 5) and stored at $-20^{\circ} \mathrm{C}$ for future molecular analyses.

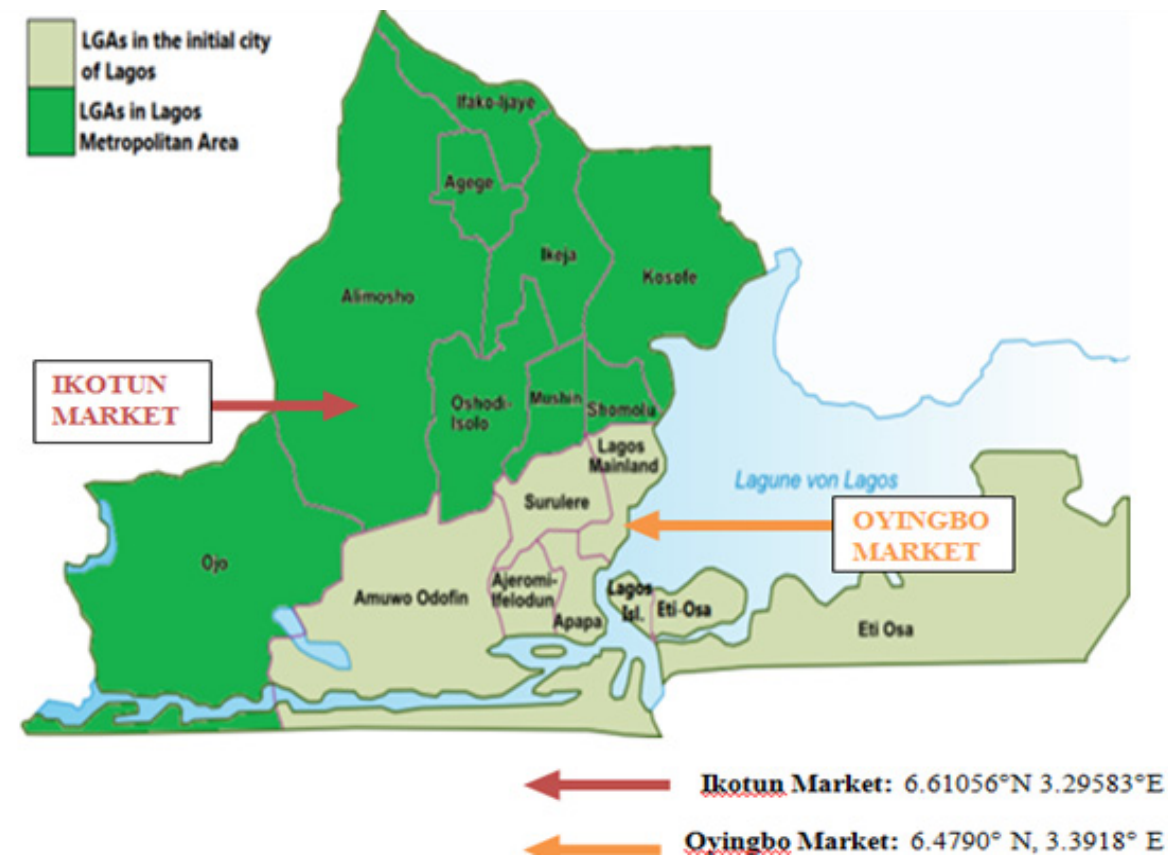

Fig. 2. Googlemap of Lagos state showing the study locations 


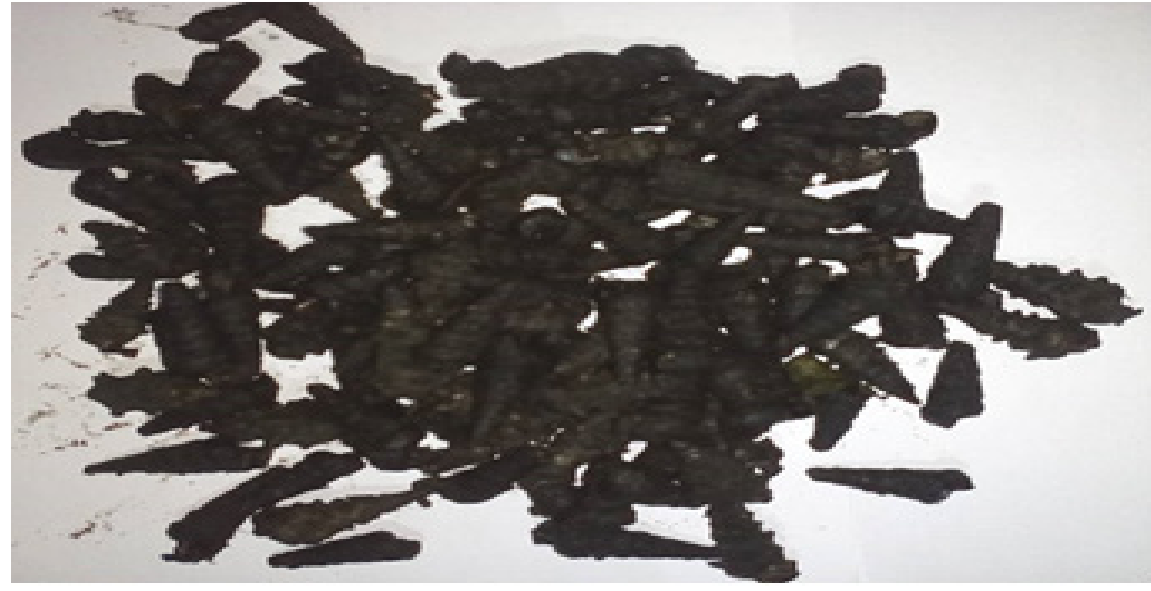

Fig. 3. Study samples (periwinkles)

$\mathrm{a}$



b



Fig. 4. (a) Processed samples (periwinkles), (b) sample processing by centrifugation
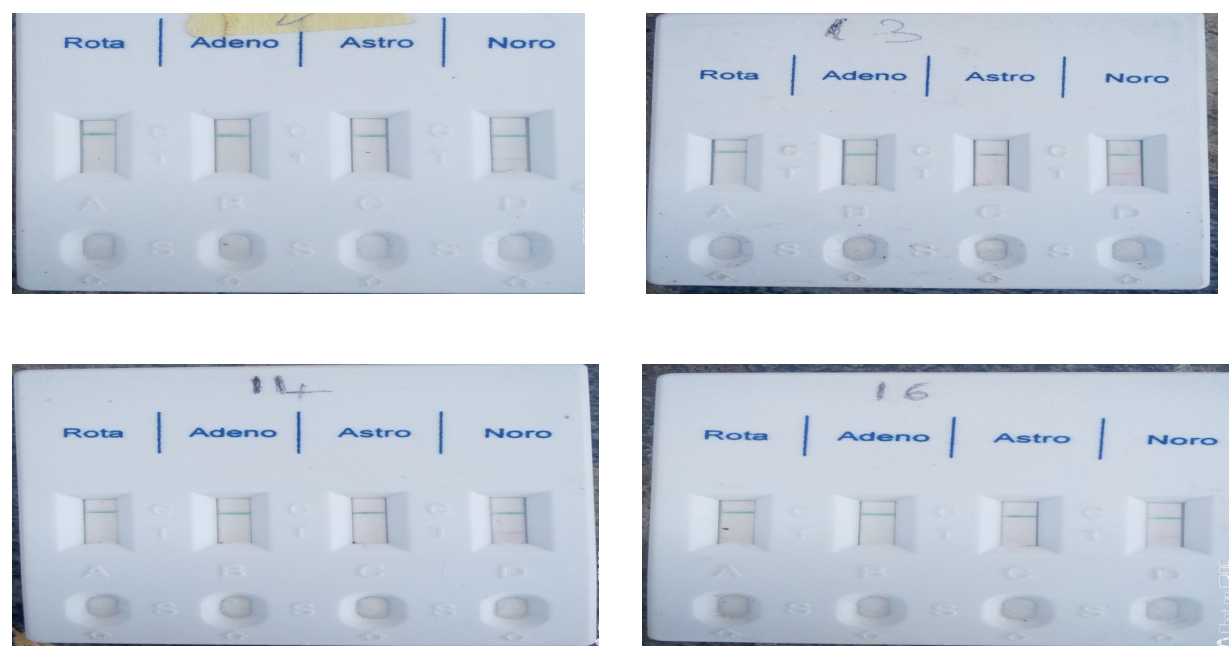

Fig. 5. Representative viral assay of the periwinkle samples showing positive results for Norovirus

Egypt. J. Food. 47, No.1 (2019) 
Screening for Enteric Viruses from Periwinkles using Lateral Flow Enzyme Immunoasssay

According to the manufacturer's instructions (CerTest ${ }^{\circledR}$ Biotec) and reported by Babalola (2018), the periwinkle samples were tested for


Biotec Rota+Adeno+Astro+Noro. On the day of screening, the samples and test kits were maintained at room temperature $\left(15-30^{\circ} \mathrm{C}\right)$ prior to testing. The pouches were not opened until the performance of the assay. The cap of the sample collection tube was taken out. About $200 \mu \mathrm{L}$ of the centrifuged supernatant (extract) was dispensed into the sample extraction buffer/ diluent. The tube was gently agitated in order to assure good sample dispersion. The mixture was left for 2 minutes so as to allow proper extraction of viral particle after which the cap of the specimen extraction tube was snapped open and 4 drops of the aliquot sample were dispensed into each of the sample port lettered A, B, C and $\mathrm{D}$ of the CerTest Rota+Adeno+Astro+Noro combo card. The results were then read after 10 min. Appearance of red band and green band at the test and control portions respectively, of the result window in the cassette indicated positive test. Absence of norovirus antigen i.e., negative result was indicated by one upper green band (1 control line) while invalid result was indicated when there was no green line or both the control line and the test line were absent. The results were then recorded accordingly. This device has an internal quality control comprising the test and control lines embedded in the cassettes which were invisible before application of sample. The control band appears only when the test procedures and reagents were performed properly.

\section{Statistical Analysis}

All data collected were analysed using descriptive statistics and Chi square at $\alpha_{0.05}$. If $\mathrm{P} \leq$ 0.05 , the differences were statistically significant.

\section{Results and Discussion}

Distribution of collected samples and rate of Norovirus detection by Month and study locations in Lagos, Nigeria

This study population consisted of 48 batches of mollusks periwinkle specimens collected from traders in two popular market locations in Lagos state and tested for the presence of rotavirus, adenovirus astrovirus and noroviruses from September 2018 to February 2019. Huang and $\mathrm{Xu}$ (2013) recommended that surveys in virology research should be more focused on pertinent issues to ensure reliable viral detection to avoiding underestimation of the presence of viruses in environmental matrices. In this study, an enzyme immunoassay based-method qualitatively detected noroviruses in periwinkles. Representative positive samples in the viral assay are shown in Figure 6. Among the targeted viruses, only the norovirus was detected in the periwinkles.

Three positive samples $(3 / 24: 12.5 \%)$ were obtained from Oyingbo market, while four positive samples (4/24:16.7\%) were obtained from Ikotun market, giving a total prevalence of $14.6 \%$ during the study period (Table 1 ). No statistically significant association was found in Norovirus detection from periwinkles at the two markets $\left(\chi^{2}=0.167, p=0.6826\right)$. Monthly rate of detection showed that the highest rate of detection occurred in the month of January at Ikotun market, while similar rate were obtained in the months of December 2018 and February 2019 at the two locations. This result is in tandem with the previous report of detection of norovirus between December-March in the United States (Wang and Deng, 2012). No virus was detected in the months of September, October and November in periwinkles from the two markets (Table 1). Similarly, statistically significant association was not found in the rate of Norovirus detection from periwinkles and the month of sample collection $\left(\chi^{2}=8.864, p=0.115, \mathrm{df}=5\right)$.

The norovirus prevalence of $14.6 \%$ in this study is in concordance with the previous $12 \%$ reported by Scales et al. (2000) from feral and farmed oysters shellfish in New Zealand. As previously reported from France (Buesa et al., 2002) in the winter of 2000-2001, in Denmark (Costantini et al., 2010), in Finland (Koopmans et al., 2003), the Netherlands (Simmons et al., 2001; Ingeborg et al., 2006; Franck et al., 2015) and South Korea (Kim et al., 2010), the potential foodborne and waterborne transmissions of these viruses from mollusks to humans and outbreak of gastroenteritis is feasible since periwinkles are lightly cooked, popularly consumed delicacies in the South-East, South-West, South-South and several parts of Nigeria.

The prevalence rate of Noroviruses in periwinkles according to this research is relatively high (14.6\%), predominantly during the cold dry months (December, January and February). This finding is in agreement with the previous report of Westrell et al. (2010) that cold winter favors the 
contamination of shellfish oysters and by extension the molluska periwinkles population, as virus survival increases in cold water temperatures and reduces exposure to ultraviolet light. Therefore, norovirus outbreaks are more likely amplified during the cold dry season in Africa. Due to the marine habitat in which periwinkles are found, they may harbor a wide variety of microorganisms including enteric viruses comprising the Rotavirus, Adenovirus, Astrovirus and Norovirus (Prado and Miagostovich, 2014). When salinity is low, viruses tend to attach to fine sediment particles or silts which provide protection to the viruses. As a result, viruses persist and remain infectious for a relatively long period of time (Maalouf et al., 2010). Therefore, salinity is considered as one of the important physio-chemical parameters affecting norovirus and related viruses prevalence in seafood.

The presence of any virus in periwinkles may be due to numerous factors such as improper disposal of sewage into water bodies or unhealthy storage of harvested periwinkles. As stated by the market women, the periwinkles were harvested by fishermen from Lagos lagoon, a brackish water habitat that is often highly polluted with sewage, while other traders purchased the harvested mollusks from Badagry waterfront from marine and fresh water sources around Lagos. This condition substantiates the previous findings of Astrom et al. (2009), that the most common route of norovirus transmission include direct release of untreated wastewater to water bodies, accidental contamination of oyster beds and seafoods with noroviruses from urban run-offs and flooding following heavy rainfalls, with attendant sewage treatment failures. Similarly, Mcleod et al. (2009) reported that enteric viruses especially noroviruses are readily bioaccumulated in oysters. After noroviruses infection, some of these viruses are internalized within cells of the digestive and nondigestive tissues and remain infectious. This discovery brings to spotlight the precarious situation that may arise from the consumption of periwinkles subjected to various unwholesome practices in the environment, during aquaculture or farming, harvesting, handling conditions, processing and distribution as previously found in an outbreak (Simmons et al., 2001).

\section{Conclusion}

Norovirus aetiology of infective diarrhoea is present at high prevalence in Nigerian harvested edible marine periwinkle. Norovirus is an enteric virus responsible for winter vomiting disease around the world. Potential outbreak of the disease is highly probable if such cuisine is improperly cooked before consumption. This study provides additional information on the reservoir of enteric viruses, demonstrating a high prevalence of norovirus in commercially-vended periwinkles in Lagos State, Nigeria. Intervention measures need to be put in place to prevent the outbreak of Noroviruses infection associated with the consumption of periwinkles. Focus on avoiding contamination by either preventing human faecal contamination in mollusk production area, or restricting commercial harvesting from faecally contaminated areas is imperative. Finally, several literature searches yielded no result of Noroviruses from food sources in Nigeria, thereby suggesting that this is the first report of Noroviruses from periwinkles in Nigeria.

TABLE 1. Overall distribution and rate of Norovirus detection by month and locations of sample collection in Lagos, Nigeria

\begin{tabular}{|c|c|c|c|c|c|c|c|}
\hline Month & \multicolumn{2}{|c|}{ Oyingbo Market } & \multicolumn{2}{|c|}{ Ikotun Market } & \multicolumn{2}{|c|}{ Total } & \multirow[t]{2}{*}{ p-value } \\
\hline & $\begin{array}{l}\text { No. of batches } \\
\text { Tested }\end{array}$ & $\begin{array}{l}\text { No. of Positive } \\
\text { Samples } \\
(\%)\end{array}$ & $\begin{array}{l}\text { No. of batches } \\
\text { Tested }\end{array}$ & $\begin{array}{l}\text { No. of Positive } \\
\text { Samples } \\
(\%)\end{array}$ & $\begin{array}{l}\text { No. of batches } \\
\text { Tested }\end{array}$ & $\begin{array}{c}\text { No. of Positive } \\
\text { Samples } \\
(\%)\end{array}$ & \\
\hline Sept & $4(16.7)$ & $0(0)$ & $4(16.7)$ & $0(0)$ & $8(16.7)$ & $0(0)$ & \\
\hline Oct & $4(16.7)$ & $0(0)$ & $4(16.7)$ & $0(0)$ & $8(16.7)$ & $0(0)$ & \\
\hline Nov & $4(16.7)$ & $0(0)$ & $4(16.7)$ & $0(0)$ & $8(16.7)$ & $0(0)$ & \\
\hline Dec & $4(16.7)$ & $1(25)$ & $4(16.7)$ & $1(25)$ & $8(16.7)$ & $2(25)$ & \\
\hline Jan & $4(16.7)$ & $1(25)$ & $4(16.7)$ & $2(50)$ & $8(16.7)$ & $3(37.5)$ & $\chi^{2}=8.864$ \\
\hline Feb & $4(16.7)$ & $1(25)$ & $4(16.7)$ & $1(25)$ & $8(16.7)$ & $2(25)$ & $p=0.115$ \\
\hline TOTAL & 24 & $3(12.5)$ & 24 & $4(16.7)$ & 48 & $7(14.6)$ & $\begin{array}{l}\chi^{2}=0.167 \\
p=0.6826\end{array}$ \\
\hline
\end{tabular}

Egypt. J. Food. 47, No.1 (2019) 
Acknowledgements : The Authors appreciate the assistance of $\mathrm{Mr}$ Akele and other technologists in the Department of Microbiology, Adekunle Ajasin University, Akungba-Akoko, Ondo State, Nigeria for storage of samples.

Declaration of funding and conflict of interests

The Authors hereby declare no funding or conflict of interests

\section{References}

Astrom, J., T.J.R. Pettersson, T.A. Stenstrom and O. Bergstedt (2009) Variability analysis of pathogen and indicator loads from urban sewer systems along a river. Water Science and Technology, 59 (2), 203212.

Babalola, M.O. (2018) One-step detection of concomitant infections, and epidemiologic profile of rotavirus, adenovirus, astrovirus and norovirus diarrhea in Nigerian infants : Implications for diarrhea burden. Canadian Journal of Pure and Applied Science, 12 (1), 4381-4394.

Benson, A.J. (2011) Littorina littorea. USGS Nonindigenous Aquatic Species Database, Gainesville, FL. https://nas.er.usgs.gov/queries/ FactSheet.

Bosch, A., R.M. Pintó and S. Guix (2014) Human astroviruses. Clinical Microbiology Reviews, 27, 1048-1074.

Buckwalter, S.P., R. Teo, M.J. Espy, L.M. Sloan, T.F. Smith and B.S. Pritt (2012) Real-time qualitative PCR for 57 human adenovirus types from multiple specimen sources. Journal of Clinical Microbiology, 50, 766-771.

Buesa, J., B. Collado, P. Lopez-Andujar, R. AbuMallouh, J. Rodriguez-Diaz, A. Garcia-Diaz, J. Prat, S. Guix, T. Lolvet, G. Prats and A. Bosch (2002) Molecular epidemiology f caliuciviruses causing outbreaks and sporadic cases of acute gastroenteritis in Spain. Journal of Clinical Microbiology, 40, 2854-2859.

Chang, A.L., A.M.H. Blakeslee, A.W. Miller and G.M. Ruiz (2011) "Establishment Failure in Biological Invasions: A Case History of Littorina littorea in California, USA". PLoS ONE, 6 (1), 16035 -16046.

Chapman, J.W., J.T. Carlton, M.R. Bellinger and A.M.H. Blakeslee (2007) "Premature" refutation of a human-mediated marine species introduction: the case history of the marine snail Littorina littorea in the northwestern Atlantic '. Biological Invasions, 9, 737-750.
Coen, L.D. and M.J. Bishop (2015) The ecology, evolution, impacts and management of hostparasite interactions of marine molluscs. Journal of Invertebrate Pathology, 131, 177- 211.

Costantini, V., L. Grenz, A. Fritzinger, D. Lewis, C. Biggs and A. Hale (2010) Diagnostic accuracy and analytical sensitivity of IDEIA Norovirus assay for routine screening of human norovirus. Journal of Clinical Microbiology, 48 (8), 27702778.

Eden, J.S., J. Hewitt, K.L. Lim, M.F. Boni, J. Merif, G. Greening, R.M. Ratcliff, E.C. Holmes, M.M. Tanaka, W.D. Rawlinson and P.A. White (2014) The emergence and evolution of the novel epidemic norovirus GII.4 variant Sydney 2012. Virology, 450-451, 106-113.

Farthing, M., M.A. Salam, G. Lindberg, P. Dite, I. Khalif and E. Salazar-Lindo (2013) Acute diarrhea in adults and children: a global perspective. Journal of Clinical Gastroenterology, 47 (1), 12-20.

Franck, K.T., M. Lisby and J. Fonager (2015) Sources of calicivirus contamination in food b or ne outbreaks in Denmark, 2005-2011 - the role of the asymptomatic food handler. Journal of Infectious Diseases, 211, 563-570.

Hardy, M.E. (2005) Norovirus protein structure and function. FEMS Microbiology Letters, 253 (1), 1-8.

Huang, G.H. and W.B. Xu (2013) Recent advances in new types of human adenovirus. Bing Du Xue Bao, 29, 342-348.

Ingeborg, L.A., J.H.C. Jeroen, A.J.M. Nathalie, V. Harry, J. Klaas, E. de Boer and K. Marion (2006) Detection of noroviruses in shellfish in the Netherlands. Journal of Food Microbiology, 108 (3), 291-396.

Kim, M., H. Lee, K. Chang and G. Ko (2010) Molecular characterization of Murine norovirus isolates from South Korea. Virus Research, 147, 1-6.

Ko, G., C. Garcia, Z. Jiang, P.C. Okhuysen, J. BelkindGerson, R.I. Glass and H.L. DuPont (2005) Noroviruses as a cause of traveller's diarrhoea among students from the United States visiting Mexico. Journal of Clinical Microbiology, 43, 6126-6129.

Koopmans, M., H. Vennema, H. Heersma, E. van Strien, Y. van Duynhoven, D. Brown, M. Reacher and B. Lopman (2003) Early identification of commonsource foodborne outbreaks in Europe.

Egypt. J. Food. 47, No.1 (2019) 
Emerging Infectious Diseases, 9, 1136-1142.

Lee, R.M., J. Lessler, R.A. Lee, K.E. Rudolph, N.G. Reich, T.M. Perl and D.A. Cummings (2013) Incubation periods of viral gastroenteritis: a systematic review. BMC Infectious Diseases, 13, 446-457.

Maalouf, H., M. Pommepuy and F.S. Le Guyader (2010) Environmental conditions leading to shellfish contamination and related outbreaks. Food and Environmental Virology, 2, 136-145.

Mcleod, C., B. Hay, C. Grant, G. Greening and D. Day (2009) Localization of norovirus and poliovirus in Pacific oysters. Journal of Applied Microbiology, 106, 1220-1230.

Medici, M.C., F. Tummolo, S. De Grazia, A. Calderaro, F. De Conto, V. Terio, M. Chironna, F. Bonura, M. Pucci, K. Banyai, V. Martella and G.M. Giammanco (2015) Epidemiological dynamics of norovirus GII.4 variant New Orleans 2009. Journal of General Virology, 96, 2919-2927.

Prado, T. and M.P. Miagostovich (2014) Detection of enteric viruses in activated sludge by feasible concentration methods. Journal of Microbiology, 45 (1), 343-349.

Rivera, R., H.H. Nollens, S. Venn-Watson, F.D. Gulland and J.F. Wellehan (2010)
Characterization of phylogenetically diverse astroviruses of marine mammals. Journal of General Virology, 91, 166-173.

Scales, G., J. Dawson and G.E. Greening (2000) Prevalence of viral pathogens in feral and farmed shellfish in New Zealand (a pilot study). ESR Client Report F65 for Ministry of Health, Porirua: ESR.

Simmons, G., C. Garbutt and J. Hewitt (2007) A New Zealand outbreak of norovirus gastroenteritis linked to the consumption of imported raw Korean oysters. New Zealand Medical Journal, 120 (1264), U2773.

Simmons, G., G. Greening, W. Gao and D. Campbell (2001) Raw oyster consumption and outbreaks of viral gastroenteritis in New Zealand: evidence for risk to the public's health. Australian and New Zealand Journal of Public Health, 25 (3), 234-240.

Wang, J. and Z. Deng (2012) Detection and forecasting of oyster norovirus outbreaks: Recent advances and future perspectives. Marine Environmental Research, 80, 62-69

Westrell, T., V. Dusch, S. Ethelberg, J. Harris, M. Hjertqvist, N. Jourdan-da Silva, A. Koller, A . Lenglet, M. Lisby and L. Vold (2010) Norovirus outbreaks linked to oyster consumption in the United Kingdom, Norway, France, Sweden and Denmark, 2010. Eurosurveillance, 15 (12), 8-11. 